\title{
Efficiency of ensilaged high-lysine maize grain in pig fattening
}

\section{M. Świątkiewicz' and J. Bojanowski²}

\author{
${ }^{\prime}$ National Research Institute of Animal Production, Department of Animal Nutrition \\ 32-083 Balice, Poland \\ :Plant Breeding and Acclimatization Institute. \\ Radzików; 05-870 Blonie, Poland
}

\begin{abstract}
In an experiment carried out on 48 fatteners, the efficacy of high-lysine maize grain in pig fattening was compared with a normal maize varicty. High-lysine maize silage is characterized by a higher content of crude protein (by $6.3 \%$ ) and lysine (by $47.9 \%$ ) in dry matter, which made it possible to decrease daily amounts of soyabean meal for experimental pigs. Intake of this component per $\mathrm{kg}$ of BWG was lower by approximately $15 \%$ during the whole fattening period. Animals in the high-lysine maize group gained slightly better, the quality of their carcasses were similar, while the protein content in $M$. longissimus dorsi was significantly higher $(\mathrm{P}<0.01)$.
\end{abstract}

KEY WORDS: high lysine maize, feeding, carcass, pig

\section{INTRODUCTION}

Maize grain is characterized by high nutrient digestibility and energy concentration, a high content of unsaturated fatty acids, $\beta$-carotene, and lack of antinutritive factors in comparison with other cereals. The protein level of maize is relatively low and poor in lysine and tryptophan. High-lysine maize varieties have been known since the 1960 s, but several agronomic disadvantages, particularly low yields, longer maturation period, soft chalky endosperm, and high susceptibility to diseases, discouraged many breeders from further investigation. Major advances in overcoming the negative effects of the opaque- 2 gene were made only recently. Maize populations superior in lysine content but similar to normal maize in yield and endosperm hardness are now available (Guang-Hai et al., 2002). A similar highlysine maize cultivar comparable to the normal variety in maturation rate but with a still slightly lower yield has been produced in Poland (Bojanowski, 2001). These results indicate that native high-lysine maize varieties can be developed further.

\footnotetext{
${ }^{1}$ Corresponding author: e-mail: mswiatki@izoo.krakow.pl
} 
Due to its shorter grain filling period and higher water content, high-lysine maize grain can easily be used for silage production, especially in cold wet regions (Pinter et al., 1995). Over the last few years, using maize grain silage in pig fattening instead of adding dried grain to feed mixtures has attracted growing attention for economic reasons.

The aim of this study was to evaluate the efficiency of high-lysine maize grain silage vs a normal maize variety in pig fattening.

\section{MATERIAL AND METHODS}

The experiment was carried out on 48 pigs originated from sows $(\mathrm{PL} \times \mathrm{LWP}$ ) mated with Duroc $\times$ Pietrain boar, divided into two groups fed restricted rations according to body weight. Group 1 received crushed standard maize grain (Wilga) silage for the whole fattening period in amounts of $1.5-2.8 \mathrm{~kg}$ daily and, as the protein component, soyabcan meal $(0.45$ to maximum $0.6 \mathrm{~kg} / \mathrm{d})$. For pigs in group 2, a silage made of high-lysine maize grain (HL 980033) was given in the same amounts, but daily rations of soyabean meal were lower by 0.05 to $0.1 \mathrm{~kg} / \mathrm{d}$. Daily feed rations for pigs in both groups contained a similar level of lysine, crude protein and energy and were supplemented with vitamins and minerals. $\Lambda$ Il animals were kept in individual, straw bedded pens and led experimental diets from about 34 to $111 \mathrm{~kg}$ body weight. At the end of the experiment all of the pigs were slaughtered, right-half carcasses were evaluated, and samples of the $M$. longissimus dorsi were taken for chemical analysis (AOAC, 1990). All data were subjected to analysis of variance (Statistica, 1997).

\section{RESULTS}

High-lysine maize grain was characterized by a higher content of crude protein (by $6.3 \%$ ) and lysine (by $47.9 \%$ ) in dry matter in comparison with normal maize. Both silages of crushed maize grain had a $\mathrm{pH}$ of 4.72-4.85 and contained approximately 76-74\% of DM. The nutritional value of $1 \mathrm{~kg} \mathrm{DM}$ of silage was comparable to that of fresh grain and the sum of lactic and acetic acids exceeded $98 \%$ of all the acids analysed, indicating limited disintegration of nutrients.

During the whole fattening period, pigs receiving high-lysine maize silage (group 2) had 1.9\% better gains and used 1.2\% less silage and $15.1 \%$ less soyabean meal $(\mathrm{P} \leq 0.01)$ per $\mathrm{kg}$ BWG than animals fed normal maize silage. The carcasses of animals in group 2 had a higher content of meat in primal cuts $(3.3 \%)$ and proper ham $(1.1 \%)$ and had a larger loin eye area $(0.9 \%)$, but these differences were not significant statistically. The content of crude protein $(3.3 \%)$ in the 
M. longissimus dorsi was significantly higher $(\mathrm{P}<0.01)$ in pigs receiving high-lysine maize silage.

TABL.F. 1

Parameters of fattening results, and carcass and meat evaluation

\begin{tabular}{|c|c|c|c|}
\hline \multirow{2}{*}{ Item } & \multicolumn{2}{|c|}{ Maize grain silage type } & \multirow{2}{*}{$\mathrm{SE}$} \\
\hline & regular & high-lysine & \\
\hline Avcrage daily body weight gains, $\mathrm{g}$ & 712 & 726 & 5.21 \\
\hline \multicolumn{4}{|l|}{ Per kg body weight gain } \\
\hline maise grain silage, $\mathrm{kg}$ & 3.28 & 3.24 & 0.06 \\
\hline soyabean meal. kg & $0.73^{13}$ & $0.62^{\mathrm{A}}$ & 0.01 \\
\hline crude protein, g & $581^{\mathrm{K}}$ & $533^{4}$ & 5.30 \\
\hline $\mathrm{ME}, \mathrm{MJ}$ & $47.89^{\mathrm{B}}$ & $44.42^{-1}$ & 0.40 \\
\hline Body weight at slaughter, $\mathrm{kg}$ & 111.2 & 111.6 & 0.34 \\
\hline Mcat content in primal cuts, kg & 24.98 & 25.81 & 0.27 \\
\hline Meat in proper ham, $\%$ & 74.07 & 74.87 & 0.45 \\
\hline Loin eyc area, $\mathrm{cm}^{2}$ & 52.76 & 53.26 & 0.87 \\
\hline Backfal thickness of 5 measurements, cm & 2.60 & 2.61 & 0.04 \\
\hline Crude protein content in $M$. longissimus dorsi, $\%$ & $21.73^{A}$ & $22.46^{\mathrm{B}}$ & 0.09 \\
\hline
\end{tabular}

$A B-13 \leq 0.01$

\section{DISCUSSION}

The fattening results of the presented experiment (Table 1) showed that leeding pigs with high-lysine grain silage and 10-20\% lower supplementation of soyabean meal compared with the control group did not significantly affect body weight gains, however, during the whole lattening period the pigs receiving this diet showed $1.9 \%$ faster gains. Animals fed high-lysine maize used less silage and soyabean meal per $\mathrm{kg}$ BWG. The possibility of improving weight gains and feed conversion ratio in fattened pigs (20-80 kg) by replacing normal maize with an equal amount of high-lysine maize was reported by Gao (2002). This indicates higher quality and digestibility of high-lysine maize protein. The results of a trial performed on pigs by Pinter et al. (1995) demonstrated that N-retention of high-lysine maize was higher and it was possible to reduce the soyabean meal content in a ration by $27 \%$. No significant influence of high-lysine maize used in grower and finisher diets for pigs instead of normal maize was found by Asche et al. (1985).

In the present experiment the carcass quality of pigs fed high- or low-lysine maize silages was comparable, but a tendency towards a higher meat content in primal cuts and proper ham as well as larger loin eye area was noticed. A significantly larger loin eye area together with comparable back lat thickness and lean meat percentage in the carcass of pigs led high-lysine maize was found in comparison with those fed the same amount of normal maize in the expcriment by Gao (2002). No significant differences in carcass quality were observed also by 
Pinter et al. (1995) for pigs fed high-lysine maize and a lower soyabean content in the diet when compared with a group receiving normal maize and a higher percentage of soyabean meal in the diet.

\section{CONCLUSIONS}

Pigs receiving ensilaged high-lysine maize grain gained slightly better and the quality of their carcasses were similar, while the protein content in the $\mathbf{M}$. longissimus dorsi was significantly higher.

The results obtained in the fattening experiment indicated that improved high-lysine maize varieties could be used for silage production as well as partial replacement of expensive protein sources such as soyabean meal.

\section{REFTRENCFS}

AOAC: 1990. Official Methods of Analysis, Association of Official Analytical Chemists. 15 Edition. Arlington, VA

Asche G.L., Lewis A.J., Peo F.R., Crenshaw J.D., 1985. The nutritional value of normal and high lysine corns for weanling and growing-finishing swine when fed at four lysine levels. J. Anim. Sci. $60,1412-1428$

Bojanowski J., 2001. Breeding ol initial plant materials for high lysine maize production (in Polish). Statutory project report, Plant Breeding and Acclimatization Institute, Rad $\angle i k o w$ (Poland)

Gao J., 2002. Nutritional cvaluation and utilization of quality protein maize Zhong Dan 9409 in pig feed. In: FAO Fxpert Consultation and Workshop on Protein Sources for the Animal Feed Industry. Bangkok (Thailand)

Guang-Hai Q,, Qi-Yu D., Yan T., Shu-Geng W., Shi-lluang 7.. 2002. Nutritional evaluation and utilization of quality protein maize (QPM) in animal leed. FAO Expert Consultation and Workshop on Protein Sources for the Animal Feed Industry. Bangkok (Thailand)

Pinter L., Burucs Z., Alloldi Z., 1995. Comparison of normal and opaque-2 maize genotypes used for corn cob mix in pig leeding. Agr. J. 87, 547-550

\section{STRESZCZENIE}

\section{Wykorzystanie kiszonego ziarna wysokolizynowej kukurydzy w tuezu świń}

W dosiwiadčeniu preprowadzonym na 48 tucznikach okresilono elektywność stosowania ziarna kukurydzy wysokolizynowcj w tuču świń w porównaniu $\angle$ odmianą standardową. Kiszonka z ziama kukurydzy wysokolizynowej zawicrała wiçecj białka ogólnego (o 6,3\%) i lizyny (o 47.9\%) w przeliczeniu na suchą masę, co pozwolilo na zmniejszenie dziennej dawki poekstrakcyjnej śruty sojowej dla tuçników grupy doświadczalnej. W całym okresie tuczu zużycie śruty sojowej na I kg pr/yrostu m.c. było w tej grupic mnicjsze o około 15\%. Tuczniki w grupie otrzymujacej kiszone ziarno kukurydzy uysokolizynowej przyrastały nieco lepiej, jakość półtusz była zbliżona, a zawartosé białka w M. longissimus dorsi byla istotnie wię̧ksza niz tuczników grupy kontrolnej. 